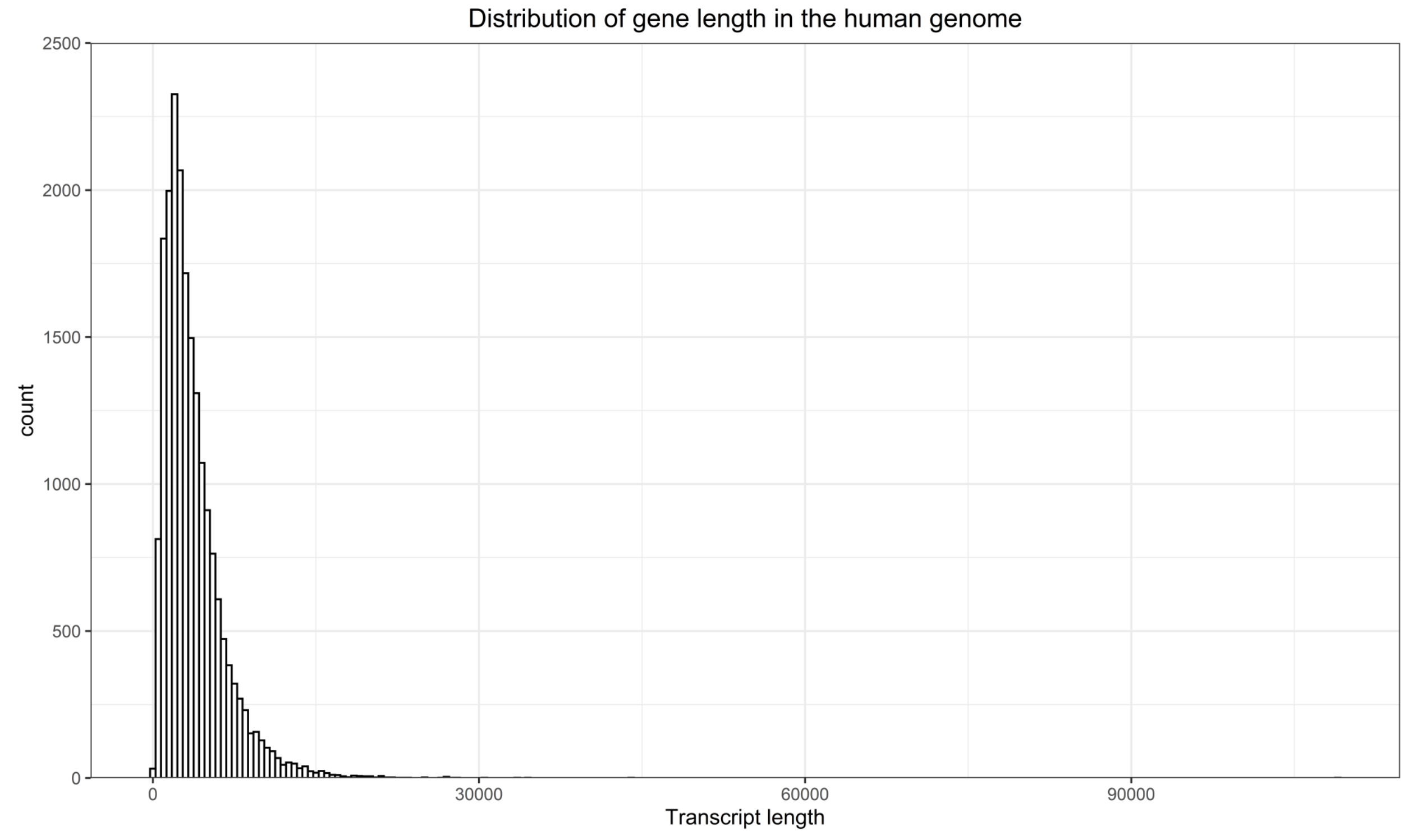

\title{
Supplementary Figure 7A.
}

Gene Length distribution in the human genome, for protein-coding genes only. Transcript Length was obtained from biomart. 


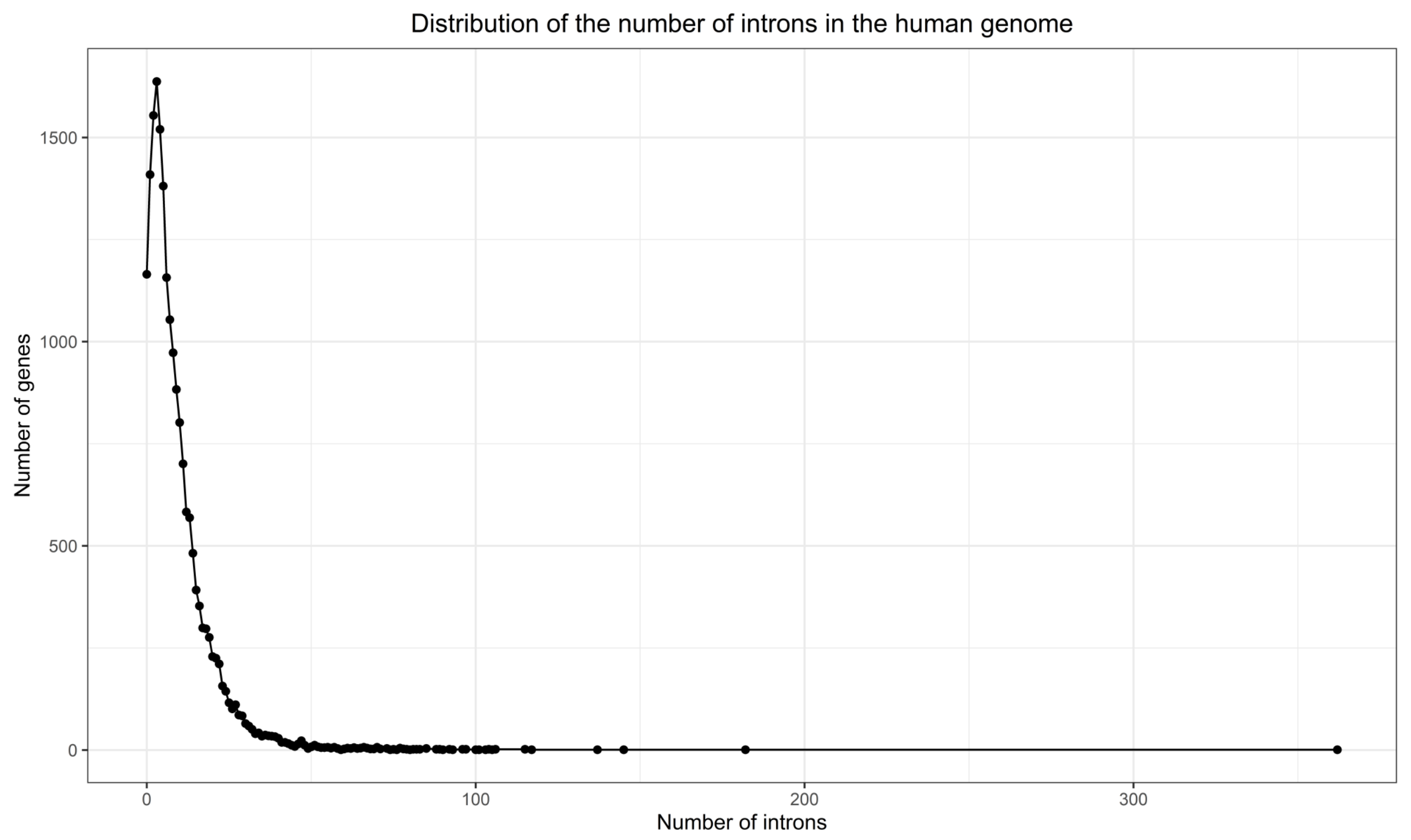

\section{Supplementary Figure 7B.}

Distributions of the number of introns in the human genome, for protein-coding genes only. The number of introns was obtained from biomart. 